\title{
Comics for Laypeople Interested in Plastination
}

\author{
Comics para Personas no Expertas Interesadas en Plastinación
}

Beom Sun Chung*; Hong-Jin Sui**; Min Suk Chung**

CHUNG, B. S.; SUI, H. J. \& CHUNG, M. S. Comics for Laypeople Interested in Plastination. Int. J. Morphol., 34(4):1105-1108, 2016.

SUMMARY: Exhibitions of plastinated specimens are popular around the world, but most people are not aware of the basics of plastination process because they are not interested in reading the related writings. Comics are an attractive medium and could solve this problem. The objective of this study was to enhance public comprehension of plastination using comics. Three topics were selected for the comics: the traditional ways to preserve dissected cadaver specimens, the plastination technique used to resolve the problems of the traditional ways, and the public display of the plastinated specimens. The 67 comic frames were drawn in simple style. The comics were available online (anatomy.co.kr) free of charge. The original files of the comics will be provided to those who utilize the files for making the signs or leaflets for exhibitions. The comics in this study, whether online or not, are expected to help people recognize the value of plastination; the comics' quantity and quality will be upgraded in a variety of ways.

KEY WORDS: Cartoons; Anatomic models; Museums; Nonprofessional education.

\section{INTRODUCTION}

Today, plastination is a familiar term even to ordinary people. This is because permanent or temporary exhibitions of plastinated cadaver specimens have become popular all over the world. Through these exhibitions, people can resolve their curiosity about the human body. However, many audiences are ignorant of general information about the plastination in spite of the exhibition signs and related leaflets. This lack of knowledge is because most laypersons are not willing to read difficult and monotonous writings. For these audiences, comics could be an optimal educational medium because of their familiarity and simplicity (Green \& Myers, 2010). Line drawing comics have been shown to be beneficial to persons learning unfamiliar and complex science concepts (Mathewson, 1999).

The purpose of the comics in the current study was to help people understand plastination. To achieve this purpose, we wrote the English manuscripts of the comics; the second author of this article has extensive experience with state ofthe-art plastination techniques (Yuan et al., 2015). We, including the corresponding author who had regularly produced anatomical comics (Park et al., 2011; Shin et al., 2013; Kim et al., 2016), then drew the comic panels for the study.

\section{MATERIAL AND METHOD}

The scope of the comics was decided: first, why and how the dissected cadaver specimens are preserved in traditional ways; second, how plastination solves the problems of traditional ways; third, how the plastinated specimens are opened to the public.

Prior to drawing the comics, we wrote out the three topics and supplementary prologue and epilogue. The stories were described logically for audiences that included children. There were few jokes because the plastination specimens are made from actual cadavers.

The corresponding author had produced the anatomy comic strips over the 15 years. In the strips, he used himself as the protagonist, "Dr. Anatophil" (Park et $a l$.). These plastination comics used the same character illustration, but the new name ("Dr. Plastina," short for "Doctor Plastination") was assigned (Fig. 1). Based on the written manuscript, simple comics were sketched on Illustrator CS6 version 16.0 (Adobe Systems, Inc., San Jose, CA, USA) (Fig. 2).

\footnotetext{
* Department of Anatomy, Ajou University School of Medicine, 164 Worldcup-ro, Suwon 16499, Republic of Korea.

** Department of Anatomy, Dalian Medical University, 9 Lushun South Road, Dalian, 116044, China.

This work was supported by the National Research Foundation of Korea (NRF) Grant funded by the Korean Government (MSIP) (No.2015R1A5A7037630).
} 


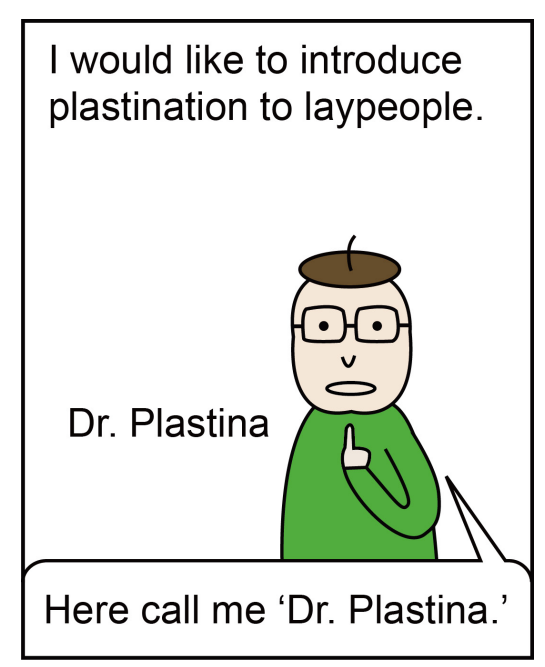

Fig. 1 Plastination comic to introduce the main character in the prologue.

\section{RESULTS}

The presented comics had only 67 frames because overly detailed information was excluded in order not to overwhelm readers; this was regarded as the main motive of the study. On the author's homepage (Department of Anatomy, Ajou University School of Medicine, 2016), comics could be watched online or captured with neither charge nor registration. The original Adobe Illustrator files of the comics (38.7 MBytes) will be provided to those who request. The files which have vector data could be easily modified or printed in any size.
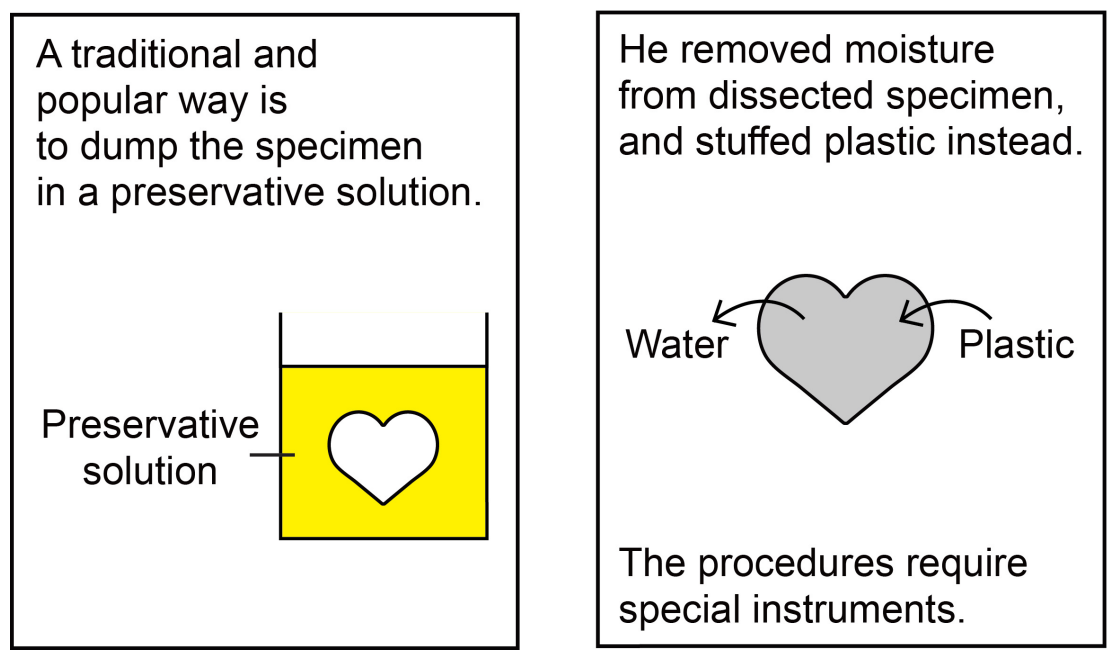

The people who have no chance to look at cadaver are shocked.

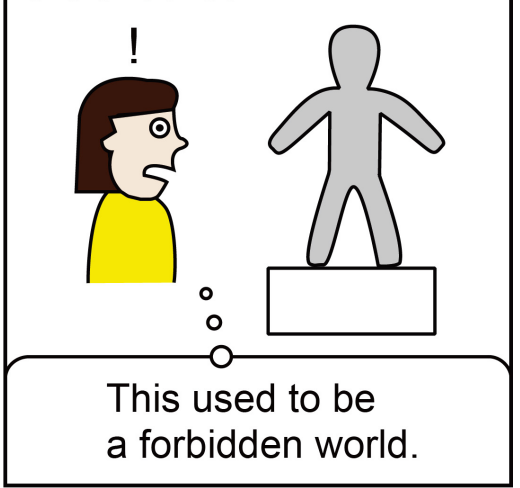

Fig. 2 Plastination comics on the traditional ways to preserve specimens (left), the plastination technique (middle), and opening to the public (right).

\section{DISCUSSION}

The comics in this study will introduce plastination to lay public effectively. It is known that comics' two information delivery methods, visual and verbal, produce a synergistic effect in learning (Liu, 2004). Consequently, people who read the comics would recognize the educational and scientific value of plastinated specimens. Persons who regarded plastinated specimens as just for show would understand their error by reading the comics. In addition, readers would grasp the plastination workers' efforts to gratify the public curiosity.
The comics available on the homepage are aimed mainly at the people who have visited or intend to visit plastination exhibits. Furthermore, the comics could be the source for the signs and leaflets in exhibits.

In these exhibits, visitors tend to concentrate on the plastinated specimens and usually bypass the text-based signs and leaflets. These comics are adequate to provide visitors with the proper messages. Visitors' responses can be determined by administering questionnaires to evaluate the educational effect of the comics. 
We had already experienced placing comics beside exhibits in a science museum (Fig. 3). Most visitors including children responded that the comics were helpful in understanding the science exhibition and in becoming familiar with the science (Chung et al., 2016.

The plastination comics are only a starting point and can be expanded quantitatively and qualitatively in the following manners.

First, the 67 cuts of comics can be increased in number as much as necessary. There are numerous academic and social stories regarding the history, technique, and exhibition of the plastinated specimens. The plenitude of the stories is being proven by the emerging international academic conferences and journals on plastination (International Society for Plastination, 2016). It is just a matter of selecting which narratives to be put into comics. Anyone can update our comics, which is why we chose to distribute the original files.

Second, the comics can be redrawn by professional cartoonists. We are amateur cartoonists who produce only simple drawings, but skilled illustrators can upgrade them.

Third, the comics can be strengthened by anatomy learning comics. We authors released an anatomy learning comics, titled "Anna \& Tommy" through the same homepage. The English comics, arranged by systems, deliver anatomical contents in a concise and logical manner (Kim et al.). The anatomy learning comics can be matched with individual plastinated specimens. For instance, the comics on skin, subcutaneous tissue, and muscles can be an orientation of the plastination specimens of the muscular system (Fig. 4). So the anatomy learning comics also can be printed as signs and leaflets.

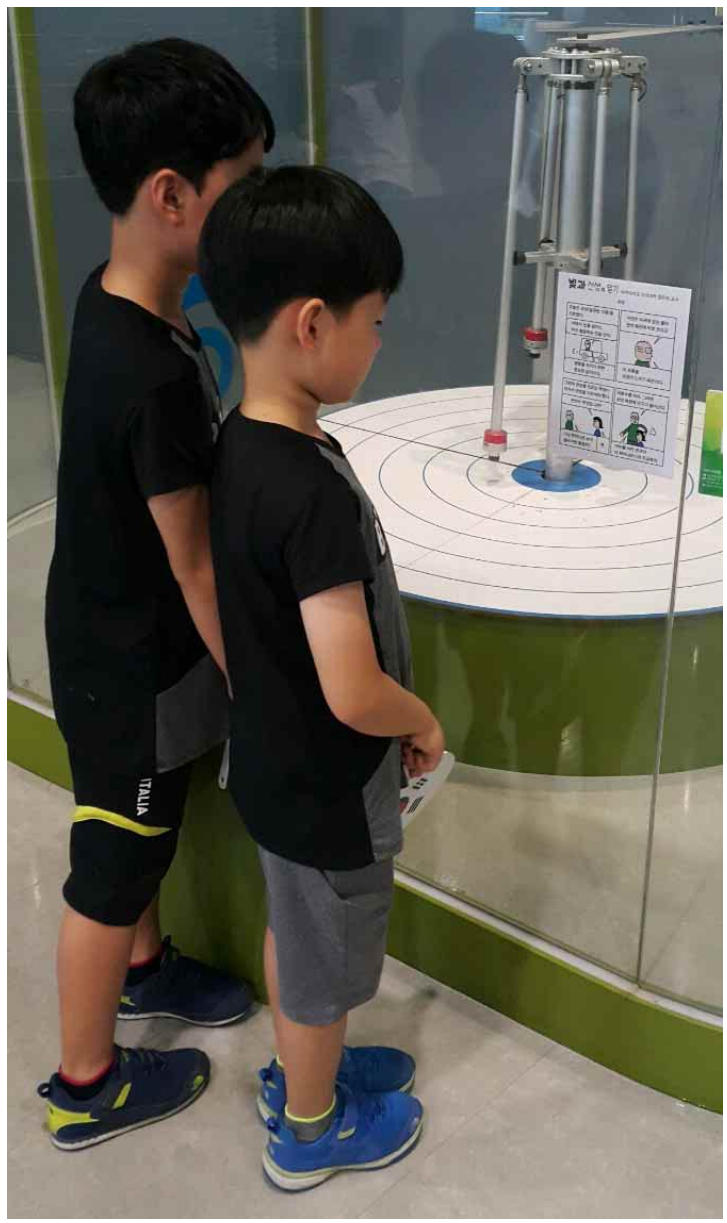

Fig. 3 Comics beside a relevant exhibit in a Korean science museum
If we look inside human body,

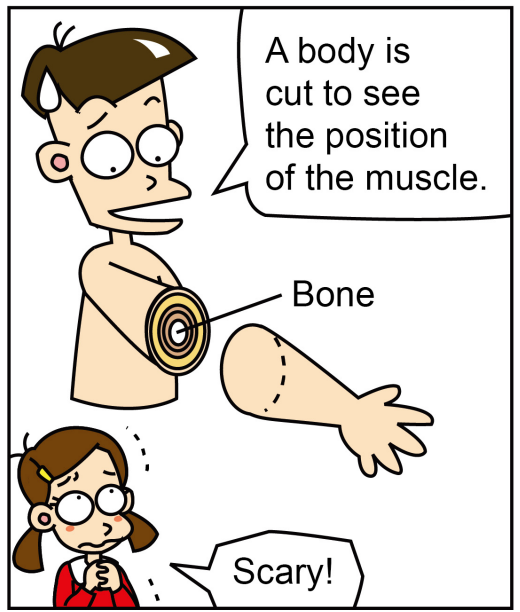

Fig. 4. Anatomy learning comics on skin, subcutaneous tissue, and muscle. the outermost part is the skin, followed by subcutaneous tissue, fascia, muscle, then bone.

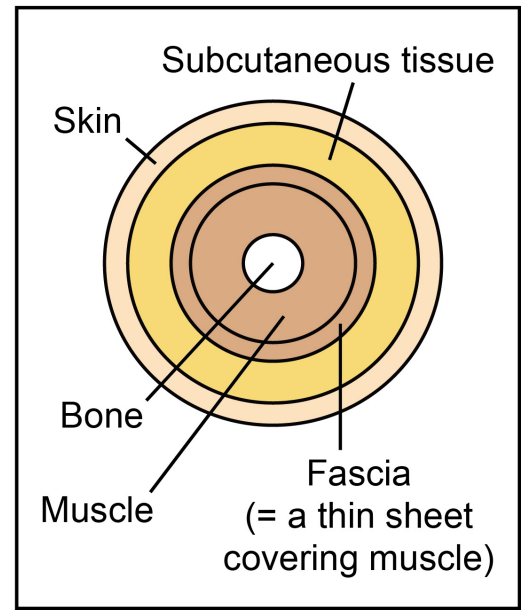

Although plastination models provide realistic features of the human body, visitors who are unfamiliar with anatomy cannot extract information from models that are similar to complex pictures (Levie \& Lentz, 1982). Unlike the models, comics provide simple images that assist in comprehension by minimizing distracting details (Fig. 4) (Houts et al., 2006).

Fourth, it is possible to produce animation about plastination based on these plastination and anatomy comics. The comics could be used as a story board in making animated.

Lastly, the comics can be translated into different languages, which would be necessary for presenting them to nations around the world. 
It is our hope that our comics will contribute to the fundamental understanding of plastination and anatomy among laypeople. The comics can be updated to enrich plastination exhibits with other interesting and informative media.

\section{ACKNOWLEDGEMENTS}

This work was supported by the National Research Foundation of Korea (NRF) Grant funded by the Korean Government (MSIP) (No.2015R1A5A7037630).

BEOM SUN CHUNG; HONG-JIN SUI; MIN SUK CHUNG. comics para personas no expertas interesadas en Plastinación. Int. J. Morphol., 34(4):1105-1108, 2016.

RESUMEN: Las exposiciones de especímenes plastinados son populares en todo el mundo, sin embargo, la mayoría de las personas no están conscientes de los conceptos básicos del proceso de plastinación debido a que no existe un interés en leer los textos relacionados. Este problema podría ser resuelto mediante historietas, las que constituyen un atractivo medio de presentación. El objetivo de este estudio fue mejorar la comprensión pública de la plastinación con el uso de historietas cómicas. Se seleccionaron tres temas de historietas: las técnicas tradicionales de preservación de cadáveres diseccionados, la técnica de plastinación, utilizada para resolver los problemas de las técnicas tradicionales de conservación, y la exhibición pública de los especímenes plastinados. Se dibujaron de manera sencilla 67 cuadros de historietas cómicas. Los cómics se encuentran disponibles en línea (anatomy.co.kr) de forma gratuita. Los archivos originales de los cómics podrán ser proporcionados a los usuarios que utilicen estos archivos para realizar avisos publicitarios o folletos para exposiciones. Esperamos que los cómics presentados en este estudio, ya sea en línea o no, sirvan de apoyo para ayudar a las personas a reconocer el valor de la plastinacion, los cuales serán actualizados de diversos modos, ya sea en cantidad como así también en relación a la calidad de los cómics.

PALABRAS CLAVE: Caricaturas; Modelos anatómicos; Museos; Educación no profesional.

\section{REFERENCES}

Chung, B. S.; Park, E. M.; KIm, S. H.; Cho, S. K. \& Chung, M. S. Comic strips to accompany science museum exhibits. J. Educ. Leam., 5(4):141-6, 2016.

Department of Anatomy, Ajou University School of Medicine. Web Site. 2016. Available from: http://anatomy.co.kr
Green, M. J. \& Myers, K. R. Graphic medicine: Use of comics in medical education and patient care. B. M. J., 340:c863, 2010.

Houts, P. S.; Doak, C. C.; Doak, L. G. \& Loscalzo, M. J. The role of pictures in improving health communication: A review of research on attention, comprehension, recall, and adherence. Patient Educ. Couns., 61(2):173-90, 2006.

International Society for Plastination. Web Site. 2016. Available from: http://isp.plastination.org

Kim, J.; Chung, M. S.; Jang, H. G. \& Chung, B. S. The use of educational comics in learning anatomy among multiple student groups. Anat. Sci. Educ., doi 10.1002/ase.1619, 2016. In press.

Levie, W. H. \& Lentz, R. Effects of text illustrations: A review of research. E. C. T. J., 30(4):195-232, 1982.

Liu, J. Effects of comic strips on L2 learners' reading comprehension. TESOL. Q., 38(2):225-43, 2004.

Mathewson, J. H. Visual-spatial thinking: An aspect of science overlooked by educators. Sci. Educ., 83(1):33-54, 1999.

Park, J. S.; Kim, D. H. \& Chung, M. S. Anatomy comic strips. Anat. Sci. Educ., 4(5):275-9, 2011.

Shin, D. S.; Kim, D. H.; Park, J. S.; Jang, H. G. \& Chung, M. S. Evaluation of anatomy comic strips for further production and applications. Anat. Cell Biol., 46(3):210-6, 2013.

Yuan, X. Y.; Yu, S. B.; Li, Y. F.; Chi, Y. Y.; Zheng, N.; Gao, H. B.; Luan, B. Y.; Zhang, Z. X. \& Sui, H. J. Patterns of attachment of the myodural bridge by the rectus capitis posterior minor muscle. Anat. Sci. Int., 91(2):175-9, 2015.

Corresponding Author:

Min Suk Chung

Department of Anatomy

Ajou University School of Medicine

164 Worldcup-ro

Suwon 16499

KOREA

Tel.: +82-10-6474-1448

Fax.: +82-31-219-5039

Email: dissect@ajou.ac.kr

Received: 28-04-2016

Accepted: 18-07-2016 